\title{
Response of termite communities to natural forest conversion
}

\author{
SRI HERIZA ${ }^{1, \vartheta}$, DAMAYANTI BUCHORI ${ }^{2}$, IDHAM SAKTI HARAHAP ${ }^{2}$, NINA MARY MNA $^{2, \text { }}$ \\ ${ }^{1}$ Program of Entomology, School of Graduates, Institut Pertanian Bogor. Jl. Raya Dramaga, IPB Dramaga Campus, Bogor 16680, West Java, Indonesia. \\ Tel./fax.: +62-251-8628448, ‘email: sriheriza08@gmail.com \\ ${ }^{2}$ Department of Plant Protection, Faculty of Agriculture, Institut Pertanian Bogor. Jl. Meranti, IPB Dramaga Campus, Bogor 16680, West Java, Indonesia. \\ Tel.: +62-251-8629354, Fax.: +62-251-8629352, ``email: ninama@apps.ac.id
}

Manuscript received: 17 August 2021. Revision accepted: 27 October 2021.

\begin{abstract}
Heriza S, Buchori D, Harahap IS, Maryana N. 2021. Response of termite communities to natural forest conversion. Biodiversitas 22: 5092-5096. Natural forest conversion can affect termite communities resulting from the various types of land use conversion. This study aims to examine the impacts of natural forest conversion on termite communities based on species richness, feeding groups, and termite species composition. Four land use types were evaluated on a gradient from the least to the most disturbing: natural forest, plantation forest, oil palm plantations and settlements. The method used to observe termites in this study is a plot measured $50 \mathrm{~m} \times 10 \mathrm{~m}$ and was divided into sub-plots of $5 \mathrm{~m} \mathrm{x} 5 \mathrm{~m}$. The termites were collected from leaf litter and soil, dead wood, trunks, and nests. The response of the termite community to the conversion of natural forest functions into other forms of land use types, where for termite species richness, there was no significant differences between land uses, but for abundance and based on feeding groups there were difference between them.
\end{abstract}

Keywords: Conversion, Dharmasraya District, natural forest, termite communities

\section{INTRODUCTION}

In recent years, natural forests have often been used as other forms of habitat by humans to meet their needs. Forest conversion can take the form of agricultural land, silviculture, and housing needs, amongst other forms (Dosso et al. 2012; Muvengwi et al. 2017; Nyirenda et al. 2019). Forest transformation affects on living things that inhabit these places, including soil fauna. According to Ahmed and Pradhan (2018), soil organisms such as termites can be used as bioindicators of the impact of environmental changes.

Termites are dominant members of the soil arthropod community in all tropical ecosystems, and their biomass may represent up to $95 \%$ of the total soil arthropod abundance (Bignell and Eggleton 2000). They are involved in the decomposition processes of various organic materials; in soil formation and weathering; in the process of consuming organic soil matter and nutrient cycles; in regulating soil hydraulic properties; and in regulating growth in the diversity of vegetation in the ecosystem (Jouquet et al. 2011).

Termites are sensitive to habitat disturbance (Bignell and Eggleton 2000). Muvengwi et al. (2017) stated that the type of land use affects the diversity and number of termite species present on a plot, with variation in the number of species in each type of land use. In habitats with certain types of land-use disturbance, a decrease in the number of termite species has been reported by Davies et al. (2020) and Hidayat et al. (2018). In these studies, the highest termite species richness was found in tropical forests, while highest diversity was found in forests that had experienced logging and disturbance. This is indicating that there was a decrease in termite species in disturbed habitats compared to undisturbed primary ones. Similar findings were reported by Pribadi et al. (2011), who found that the conversion of natural forest land into forests developed for tourism, production forests, agroforestry, and settlements reduced termite species richness. Gillison et al. (2003) found that the number of termite species was around 34 in primary forests, falling to only one in monoculture-type gardens.

However, in contrast to these findings, not all disturbance reduces the number of species. For example, some appear to be relatively resistant to disturbances such as fire; the conversion of natural forests into new functions by burning did not reduce the number of termite species (Avitabile et al. 2015). Materu et al. (2013) showed that there was no significant different in termite species richness under different habitats in Rufiji District Tanzania, but that abundance differed between agricultural land, forests, and grasslands. In a study of peatlands, Neoh et al. (2016) found that overall termite species richness in peatland affected by fires was not significantly different from in peat forests, but that fires significantly changed the structure of termite communities.

With these contradictory scenarios, it is important to research whether changes in land use type due to forest transformation affect termite communities. Specifically, communities can be studied from the diversity and composition of species. In Indonesia, while research conducted by Sholih (2017) was limited to studying the diversity of termites in secondary forest habitats, rubber forests, rubber plantations, and oil palm plantations, it did not examine the composition of termites in converted land. 
Detailed studies on the impact of natural forest conversion on termite communities are still lacking.

We therefore examine the effect of land conversion on termite communities in Dharmasraya District, West Sumatra Province. Many natural forests have undergone conversion into plantations and settlements. Natural forests have been opened up by burning. In this district, such forests are sometimes cleared initially for oil palm plantations, but then left abandoned, so resulting forestry. This study aims to examine the impacts of natural forest conversion on termite communities based on species richness, feeding groups, and termite species composition. Four land use types were evaluated in a gradient from least to most disturbing: natural forest, plantation forest, oil palm plantations and settlements.

\section{MATERIALS AND METHODS}

\section{Study site}

The research was conducted in Dharmasraya District, West Sumatra $\left(00^{\circ} 48^{\prime} 25.4^{\prime \prime}-01^{\circ} 41^{\prime} 40.3^{\prime \prime S}\right.$ and $\left.101^{\circ} 08^{\prime} 32.5^{\prime \prime}-101^{\circ} 53 ' 30.3^{\prime \prime E}\right)$, from October to December 2018. The range of rainfall in the three months based on data from the Sicincin Class II Climatology Station, Padang Pariaman was 342-452 $\mathrm{mm}^{3}$. Sampling was conducted on four different land use types, namely natural forest (NF), plantation forest (PF), oil palm plantations (OPP) and settlements (S). The four types of land use were selected based on the different levels of disturbance experienced. Observation of the termite communities based on the level of habitat disturbance due to land use activities followed the approach of Bickel and Watanasit (2005). The assessment was based on the level of habitat disturbance, namely: (i) the number of large diameter $(\varnothing \geq 20 \mathrm{~cm})$ trees; (ii) the existence of lower plants (lower than trees); (iii) the amount of canopy stratification; (iv) the direct exposure of sunlight to the ground; and (v) the level of accessibility to the region.

\section{Termite sampling technique}

The research was conducted in Dharmasraya District in 11 sub-districts with four types of land use in each, giving 44 sites in all. The characteristics of each type of land use are shown in Table 1.
The method used to observe the termites was a modified version of that developed by Jones and Eggleton (2000). Each observation plot measured $50 \mathrm{~m} \times 10 \mathrm{~m}$ and was divided into sub-plots of $5 \mathrm{mx} 5 \mathrm{~m}$, meaning 20 observation sub-plots were created. Each sub-plot was surveyed for 30 minutes, totalling 10 hours' observation at each site (Eggleton et al. 2002; Jones et al. 2005).

\section{Termite collection}

Each termite found in the observation sub-plot was collected from the soldier and worker castes. The termites were put into a collection bottle containing $70 \%$ alcohol and then labelled for identification purposes. This enabled the abundance of termites to be determined based on the number of findings of a species in each land use type.

The termites were collected from: 1) leaf litter and soil taken by digging $5 \mathrm{~cm}$ below the ground surface; 2) dead wood with a diameter of $>1 \mathrm{~cm}$; 3) trunks or buttresses containing large amounts of litter or organic soil matter in the vicinity, which were observed, buttresses and slabs opened, and termites located up to a height of $\pm 2 \mathrm{~m}$; and 4) nests and mounds on the ground (Jones and Eggleton 2000). Each subsite was systematically surveyed (Houston et al. 2015).

\section{Termite identification}

Termites were identified to the morphospecies level using termite identification keys (Ahmad 1958; Tho 1992; Syaukani 2006). Morphological observations were made on soldier caste because, differences in form in this caste are very striking compared to other castes, especially near the mandibles, enabling genera to be easily distinguished.

The termites were grouped based on their diet. The food groups included: 1) wood-litter feeders (WL); 2) wood feeders (W); 3) epiphyte feeders (E) and 4) soil feeders (S) (Collins 1984).

\section{Data analysis}

The diverse data were tabulated into a database. Data on the number of termite species were then compared between land use types using ANOVA. Cluster analysis was used to compare the similarity of termite communities between land use types.

Table 1. Characteristics of each type of land use at the study sites

\begin{tabular}{|c|c|c|c|c|}
\hline & NF & PF & OPP & $\mathbf{S}$ \\
\hline $\begin{array}{l}\text { Number of trees } \emptyset \\
\geq 20 \mathrm{~cm}\end{array}$ & $>210$ individu./acre & $>150$ individu./acre & $<150$ individu./acre & $<50$ individu./acre \\
\hline $\begin{array}{l}\text { Lower plants } \\
\text { (lower than trees) }\end{array}$ & $\begin{array}{l}\text { Shrubs, grasses, } \\
\text { mushrooms, ferns }\end{array}$ & $\begin{array}{l}\text { Shrubs, grasses, mushrooms, } \\
\text { ferns }\end{array}$ & Grasses, ferns & - \\
\hline Canopy & 3 layers, very close & 2 layers, close & 1-2 layers, open & 1-2 layer, very open \\
\hline $\begin{array}{l}\text { Easy to reach the } \\
\text { sites }\end{array}$ & $\begin{array}{l}\text { Very rare; hunting and } \\
\text { looking for grass }\end{array}$ & $\begin{array}{l}\text { Rarely; looking for grass, an } \\
\text { alternative route }\end{array}$ & $\begin{array}{l}\text { Often; seasonal } \\
\text { agricultural land }\end{array}$ & $\begin{array}{l}\text { Very often; agriculture } \\
\text { and settlement }\end{array}$ \\
\hline Age & Unknown & $\begin{array}{l}>15 \text { years after oil palm } \\
\text { plantations were abandoned }\end{array}$ & $8-15$ years & Unknown \\
\hline
\end{tabular}




\section{RESULTS AND DISCUSSION}

\section{Termite diversity}

Fourteen termite species belong to six subfamilies and two families, Rhinotermitidae and Termitidae were identified (Table 2). Termitinae and Nasutitermitinae had the most species (four species each), followed by Rhinotermitinae and Macrotermitinae (two species each). Two subfamilies, Coptotermitinae and Heterotermitinae, had the lowest number species, with only one species each. Natural forest and oil palm plantations had the highest number of termite species ( 8 species), while seven were found in the plantation forest and only three in the settlements. The highest abundance of termites was found in natural forests (29 encounters in total), with the lowest in the settlements (18). Plantations represented an intermediate level, with 25 encounters in oil palm plantations and 23 in plantation forests.

Analysis of the variance showed that while land use did not influence termite species richness $\left(\mathrm{F}_{3.36}=1.599, \mathrm{p}=\right.$ $0.207)$, it influenced the abundance of termites $\left(F_{3.36}=\right.$ $3.191, \mathrm{p}=0.0351)$.

\section{Termite composition}

Examination of the subfamily composition of termite species in each type of land use shows that natural forest and plantation forest were dominated by Termitinae and Nasutitermitinae, both of which were absent from settlements (Figure 1). Nasutitermitinae was also absent from oil palm plantations. Two subfamilies (Coptotermitinae and Heterotermitinae) were absent from natural forest and plantation forest, but present in the two more highly disturbed land. Rhinotermitinae was found only in plantations forest and oil palm; while Macrotermitinae were found in all four land use types.

Termite composition was also examined based on diet (Table 2). Out of the 14 species, ten were wood feeding termites, two fed on soil/humus, with one species each in the wood-litter feeder and epiphytic feeder categories. Wood feeding termites such as Macrotermes gilvus and Microtermes sp.1 are also known to cultivate fungus as a source a food. Based on the feeding groups, termites with wood feeding habits dominated in all land-use types (Figure 2). Soil/humus feeding termites were absent from settlements, while epiphyte feeders were present only in natural forest. Wood-litter feeding termites were found in oil palm plantations and settlements.

\section{Discussion}

The highest abundance of termite is in natural forest habitats and the lowest is in settlements. Regarding the vegetation, plantation forests have a higher level than oil palm plantations. However, the existing abundance did not guarantee high abundance of termite in the plantation forest. This is because the conversion of natural forest is usually made by burning, but the termite community is able to defend itself from fire disturbances (Davies et al. 2013; Avitabile et al. 2015). Thus the termite community remains where it came from, even though new environmental conditions are formed.
The termite species richness in this study was low when compared to that found by Sholih (2017) that has done in June during the dry season. It is possible that there is an influence of rainfall factors; this research was conducted during the rainy season. According to Dibog et al. (1999), there is a decrease in the number of termite species in high rainfall intensity. High annual rainfall and seasonal flooding have been reported to make it difficult for termites to nest and find food. The difference in the species richness of termite is thought to be due to different physical needs (Susilo and Aini 2005). Termite species richness did not have a significant effect on the four study types of land. Similarly, the report by Materu et al. (2013) showed no significant different in termite species richness in agricultural land, forests, and grasslands.

According to this study, three sub families (Coptotermitinae, Heterotermitinae, and Macrotermitinae) were found in oil palm plantation which were also found in settlements. But they were not found in natural forest, and plantation forest. According to Nandika et al. (2003), the Macrotermitinae and Coptotermitinae are generally more destructive in nature; those capable of causing damage are termites of the genus Coptotermes and Macrotermes. This indicates that a change in termite composition reflects a change in habitat structure, from a closed, moist forest with little light penetration, to a much more open one with totally different soil conditions. It may be that these changed soil conditions enable different species to thrive.

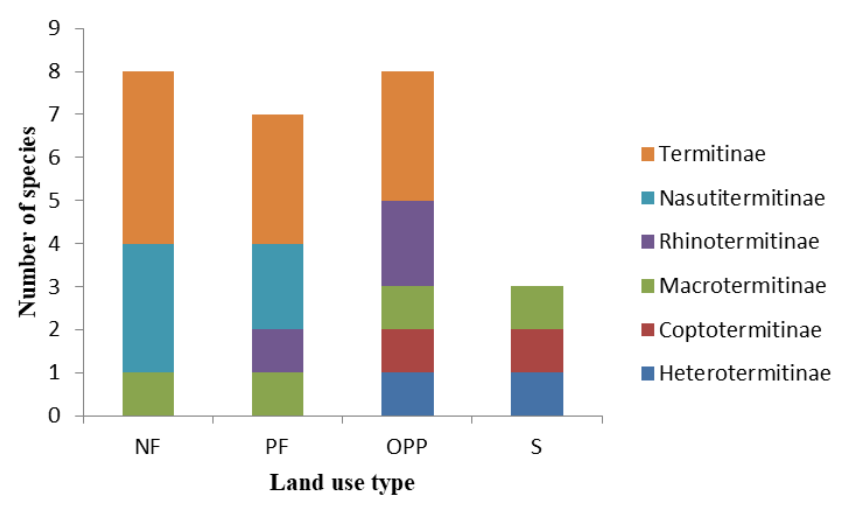

Figure 1. Subfamily composition of termite species in the four land use

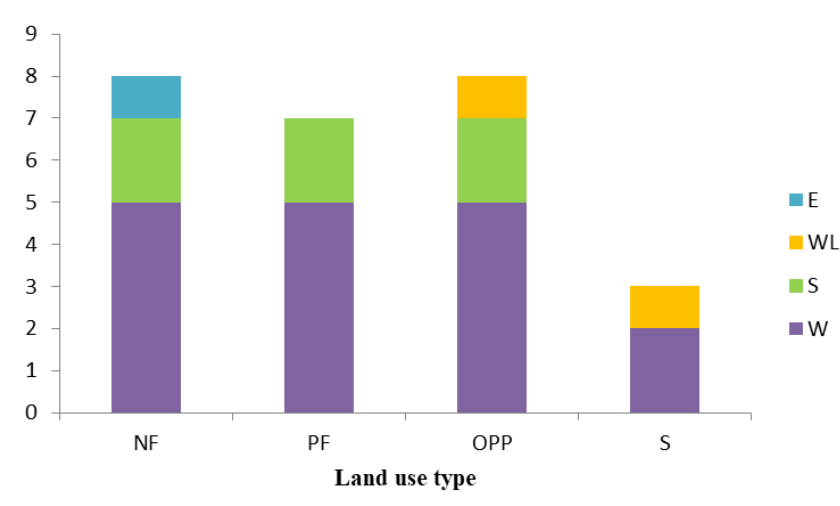

Figure 2. Termite feeding groups in the four land-use 
Table 2. Abundance of species of termites in the four different types of land use in Dharmasraya District (FG=feeding group, $\mathrm{WL}=$ wood-litter feeders, $\mathrm{W}=$ wood feeders, $\mathrm{E}=$ epiphyte feeders, $\mathrm{S}=$ soil feeders $(\mathrm{S})$

\begin{tabular}{|c|c|c|c|c|c|}
\hline Taxon & Natural forest & Plantation forest & Oil palm plantation & Settlement & FG \\
\hline \multicolumn{6}{|l|}{ Rhinotermitidae } \\
\hline \multicolumn{6}{|l|}{ Coptotermitinae } \\
\hline Coptotermes curvignathus & 0 & 0 & 2 & 4 & W \\
\hline \multicolumn{6}{|l|}{ Rhinotermitinae } \\
\hline Schedorhinotermes longirostris & 0 & 3 & 2 & 0 & $\mathrm{~W}$ \\
\hline Schedorhinotermes sp.1 & 0 & 0 & 3 & 0 & W \\
\hline \multicolumn{6}{|l|}{ Termitidae } \\
\hline \multicolumn{6}{|l|}{ Heterotermitinae } \\
\hline Heterotermes sp. 1 & 0 & 0 & 1 & 1 & W \\
\hline \multicolumn{6}{|l|}{ Termitinae } \\
\hline Globitermes globosus & 2 & 1 & 2 & 0 & $\mathrm{~W}$ \\
\hline Pericapritermes sp. 1 & 1 & 0 & 1 & 0 & S \\
\hline Percapritermes sp. 2 & 9 & 6 & 3 & 0 & S \\
\hline Termes sp. 1 & 5 & 4 & 0 & 0 & $\mathrm{~W} / \mathrm{S}$ \\
\hline \multicolumn{6}{|l|}{ Macrotermitinae } \\
\hline Macrotermes gilvus & 0 & 0 & 11 & 13 & WL \\
\hline Microtermes sp.1 & 8 & 6 & 0 & 0 & $\mathrm{~W}$ \\
\hline \multicolumn{6}{|l|}{ Nasutitermitinae } \\
\hline Bulbitermes neopusillus & 1 & 2 & 0 & 0 & $\mathrm{~W}$ \\
\hline Hospitalitermes hospitalis & 1 & 0 & 0 & 0 & $\mathrm{E}$ \\
\hline Nasutitermes havilandi & 2 & 0 & 0 & 0 & $\mathrm{~W}$ \\
\hline Nasutitermes longinasus & 0 & 1 & 0 & 0 & W \\
\hline Index of abundance (based on encounters) & 29 & 23 & 25 & 18 & \\
\hline Number of termite species & 8 & 7 & 8 & 3 & \\
\hline
\end{tabular}

Wood termites are found in all types of land use. This shows that the response to eating wood is very tolerant of all forms of natural forest conversion. Most wood-eating termites are found in disturbed habitats and also in natural forests with open environmental conditions and low humidity levels, habitats in which abundant dry wood is found. The high adaptability of wood food groups is influenced by the exploitation of different food resources in different habitats (Li et al. 2015).

Soil feeders are found in natural forests, plantation forests, and oil palm plantations but not in settlements. These three habitats have moist soil. According to Eggleton et al. (2002), soil feeder termites respond to high humidity and canopy to shade their habitat and retain moisture. When land is converted, the microclimate changes (Hardwick et al. 2015). The reduction in canopy cover results in increased exposure to direct sunlight that reaches the soil surface. In addition, the reduction in the number of leaves makes the temperature increase and can reduce humidity (Hardwick et al. 2015), thus affecting this group of termites.

Wood litter feeders are found only in settlements. Highly exposed environmental conditions favor this food group with the associated excessive disturbance compared to other land uses in this study. Such feeders are the type of termite Macrotermes gilvus. The Macrotermes group usually forms mounds of earth useful for the defense of their colonies from predators and act as shelters from extreme environmental disturbances (Noirot and Darlington, 2000). Furthermore, the mound above the ground serves as a link between the caste of soldiers and caste workers in their activities in the form of closed galleries (Merritt and Starr, 2010). All of this is a termite nesting strategy in order to defend its colony. In addition, termites from this group have sclerotization on the bodies of both the soldier and worker castes. This is a form of termite self-defense from high temperatures and lower soil surface moisture compared to the soil's buffer environment (Rajpurohit et al. 2008; Schimpf et al. 2011).

Epiphytic feeders are only found in natural forests, with only represented by one species, Hospitalitermes hospitalis. The workers and soldiers castes of Hospitalitermes usually forage in columns on tree trunks, on logs and in leaf litter on the forest floor (Syaukani 2014; Syaukani et al. 2016). Based on this study, this termite was not found in several other types of use, because the epiphytic feeder termite is very typical of the nest, with the nest made from hard soil, being mound-shaped with two entrances, and its surface covered by lichen.

In conclusion, the response of the termite community to the conversion of natural forest functions into other forms of land use types, where for termite species richness, there was no significant differences between land uses, but for abundance and based on feeding groups there were difference between them.

\section{ACKNOWLEDGEMENTS}

We would like to express thanks to the Beasiswa Pendidikan Pascasarjana Dalam Negeri (BPPDN) which supported this research through funding and to all the 
parties who participated in helping the research run smoothly.

\section{REFERENCES}

Ahmad M. 1958. Key to the Indomalayan Termites. University of the Punjabi, Lahore.

Ahmed JB, Pradhan B. 2018. Termite mounds as bio-indicators of groundwater: Prospects and constraints. Pertanika J Sci Technol 26 (2): 479-498.

Avitabile SC, Dale GN, Andrew FB, Clarke MF. 2015. Termites are resistant to the effects of fire at multiple spatial scales. Plos One 10 (11): e0140114. DOI: 10.1371/journal.pone.0140114.

Bickel TO, Watanasit S. 2005. Diversity of leaf litter ant communities in Ton Nga Chang Wildlife Sanctuary and nearby rubber plantations, Songkhla, Southern Thailand. Songklanakarin J Sci Technol 27 (5): 944-955.

Bignell DE, Eggleton P. 2000. Termites in ecosystems. In: Abe MH, Bignell DE (eds). Termites: Evolution, Sociality, Symbioses, Ecology. Kluwer Academic Press, Dordrecht, The Netherlands.

Collins NM. 1984. The termites (Isoptera) of the Gunung Mulu National Park, with a key to the genera known from Sarawak. Sarawak Mus J 30: 65-87. DOI: 10.1111/j.1365-2311.1979.tb00580.x.

Davies AB, van Rensburg BJ, Eggleton P, Parr CL. 2013. Interactive effects of fire, rainfall, and litter quality on decomposition in savannas: Frequent fire leads to contrasting effects. Ecosystems 16: 866-880. DOI: 10.1007/s10021-013-9657-0.

Davies AB, Philip GB, Catherine LP, Gregory PA. 2020. Resistance of mound-building termites to anthropogenic land-use change. Environ Res Lett 15: 094038. DOI: 10.1088/1748-9326/aba0ff.

Dibog L, Eggleton P, Norgrove L, Bignell DE, Hauser S. 1999. Impacts of canopy cover on soil termite assemblages in an agrisilvicultura system in Southern Cameroon. Bull Entomol Res 89: 125-132. DOI $10.1017 /$ S0007485399000206.

Dosso K, Kolo Y, Souleymane K, Karl EL. 2012. Importance of protected areas for biodiversity conservation in central Côte d'Ivoire: Comparison of termite assemblages between two neighboring areas under differing levels of disturbance. J Insect Sci 12: 131. DOI 10.1673/031.012.13101.

Eggleton P, Bignell DE, Hauser S, Dibog L, Norgrove L. Madong B. 2002. Termite diversity across an anthropogenic gradient in the humid forest zone of West Africa. Agric Ecosyst Environ 90: 189-202. DOI: 10.1016/S0167-8809(01)00206-7.

Gillison A, Jones AN, Susilo FX, Bignell DE. 2003. Vegetation indicates diversity of soil macroinvertebrates: A case study with termites along a land-use intensification gradient in lowland Sumatra. Org Diver Evol 3: 111-126. DOI: 10.1078/1439-6092-00072.

Hardwick SR, Toumi R, Pfeifer M, Turner EC, Nilus R, Ewers RM. 2015 The relationship between leaf area index and microclimate in tropical forest and oil palm plantation: forest disturbance drives changes in microclimate. Agric For Meteorol 201: 187-195. DOI 10.1016/j.agrformet.2014.11.010.

Hidayat MR, Wahyu ME, Yulia D. 2018. Effect of a rubber plantation on termite diversity in Melawi, West Kalimantan, Indonesia. Agric Nat Res 52 (5): 439-444. DOI: 10.1016/j.anres.2018.10.016.

Houston WA, Wormington KR, Black RL. 2015. Termite (Isoptera) diversity of riparian forests, adjacent woodlands and cleared pastures in tropical eastern Australia. Austral Entomol 54: 221-230. DOI 10.1111/aen.12115.

Jones DT, Eggleton P. 2000. Sampling termite assemblages in tropical forests: testing a rapid biodiversity assessment protocol. J Appl Ecol 37:191-203. DOI: 10.1046/j.1365-2664.2000.00464.x.

Jones DT, Verkerk RHJ, Eggleton P. 2005. Methods for sampling termites. Leather SR (eds.). Insect Sampling in Forest Ecosystems. Blackwell, Malden.
Jouquet P, Traore S, Choosai, C, Hartmann C, Bignell D. 2011. Influence of termites on ecosystem functioning. Ecosystem services provided by termites. Eur J Soil Biol 47: 215-222. DOI: 10.1016/j.ejsobi.2011.05.005.

Li HF, Lan YC, Fujisaki I, Kanzaki N, Lee HJ, Su NY. 2015. Termite assemblage pattern and niche partitioning in a tropical forest ecosystem. Environ Entomol 44: 546-556. DOI: 10.1093/ee/nvv038.

Materu C, Jacob Y, Bruno N. 2013. Seasonal changes on termite foraging behaviour under different habitats in Rufiji District Tanzania. J Biol Agric Healthc 3(11): 6-11. DOI: pdf/234659033.pdf.

Merritt NRC, Starr CK. 2010. Comparative nesting habits and colony composition of three arboreal termites (Isoptera: Termitidae) in Trinidad \& Tobago, West Indies. Sociobiology 56 (3): 611-622.

Muvengwi J, Monicah M, Hilton GT, George N, Polite N. 2017. Termite diversity along a land use intensification gradient in a semi-arid savanna. J Insect Conserv 21: 801-812. DOI: 10.1007/s10841-0170019-7.

Nandika D, Rismayadi Y, Diba F. 2003. Rayap, Biologi dan Pengendaliannya. Muhammadiyah University Press, Surakarta. [Indonesian]

Neoh KB, Bong LJ, Muhammad A, Itoh M, Kozan O, Takematsu Y, Yoshimura. 2016. The impact of tropical peat fire on termite assemblage in Sumatra, Indonesia: Reduced complexity of community structure and survival strategies. Environ Entomol 45 (5): 1170-1177. DOI: $10.1093 / \mathrm{ee} / \mathrm{nvw} 116$.

Noirot C, Darlington J. 2000. Termite nests: Architecture, regulation and defence. In: Abe T, Bignell DE, Higashi M (eds). Termites: Evolution, Sociality, Symbioses, Ecology. Kluwer Academic Publishers, Amsterdam.

Nyirenda H, Emeline PS, Paxie WC, Coert G, Francis WN. 2019. The effect of land use change and management on the vegetation characteristics and termite distribution in Malawian Miombo woodland agroecosystem. Agroforest Syst 93 (6): 1-13 DOI: 10.1007/s10457-019-00358-8.

Pribadi T, Raffiudin R, Harahap IS. 2011. Termites community as environmental bioindicators in highlands: A case study in eastern slopes of Mount Slamet, Central Java. Biodiversitas 12 (3): 235-240. DOI: 10.13057/biodiv/d120409.

Rajpurohit SR, Parkash, Ramniwas S. 2008. Body melanization and its adaptive role in thermoregulation and tolerance against desiccating conditions in drosophilids. Entomol Res 38: 49-60. DOI: 10.1111/j.1748-5967.2008.00129.x.

Schimpf NG, Philip GDM, Craig RW. 2011. Cockroach that exchange respiratory gases discontinuously survive food and water restriction. Evolution 66-2: 597-604. DOI: 10.1111/j.1558-5646.2011.01456.x.

Sholih MD. 2017. Keanekaragaman spesies dan layanan ekosistem rayap dan semut pada berbagai tipe penggunaan lahan di Jambi. [Thesis]. IPB University, Bogor. [Indonesian]

Susilo FX, Aini FK. 2005. Diversity and density of termite in a range of land use types in the rigis hill area, Sumberjaya-Lampung. Jurnal Sains Teknologi 11 (3):129-136.

Syaukani. 2006. A Guide to the Nasus Termites (Nasutitermitinae, Termitidae) of Kerinci Seblat National Park Sumatera. Mitra Barokah Abadi, Yogyakarta, Indonesia.

Syaukani. 2014. Biosystematics of Hospitalitermes hospitalis Holmgren (Isoptera) from Borneo. Proceedings of The 4th Annual International Conference Syiah Kuala University (AIC Unsyiah) 2014 In conjunction with The 9th Annual International Workshop and Expo on Sumatra Disaster Tsunami Disaster and Recovery AIWEST-DR 2014. Banda Aceh, Indonesia, October 22-24, 2014.

Syaukani, Thompson GJ, Zettel H, Pribadi T. 2016. A new species of open-air processional column termite Hospitalitermes nigriantennalis sp.n. (Termitidae), from Borneo. Zookeys 554: 27-38. DOI: 10.3897/zookeys.554.6306

Tho YP. 1992. Termites of Peninsular Malaysia. Forest Research Institute Malaysia, Kepong, Kuala Lumpur. 